\title{
Not quiet on the Tasman front? The trans-Tasman rivalry in New Zealand's Great War cartoons
}

\author{
Steven Loveridge \\ Stout Research Centre, Victoria University of Wellington, New Zealand \\ fourfort@hotmail.com
}

\begin{abstract}
There is a fascinating idiosyncrasy within New Zealand cartoonist's depiction of Australia during the Great War. Running parallel to comradely images of fresh-faced ANZACs marching together, New Zealand cartoonists produced acrimonious sketches of their neighbour and ally as dysfunctional and even disloyal. These representations might be considered as charting the limits of neighbourly sentiments and goodnatured humour. This article surveys the context, in history and humour, behind these depictions and questions how they fit within the wider panorama of New Zealand's war effort and the humorous irreverence conventionally considered to be a key aspect of the trans-Tasman relationship.
\end{abstract}

Keywords: New Zealand humour; Australia; war humour; political humour; cartoons.

\section{Introduction}

On 12 January 1918, the front page of the New Zealand Observer featured a cartoon of a brutish figure waving a Prussian war flag with one hand, and gripping a bloody dagger in the other. As the brute marches forward, his boot, inscribed with the text "made in Germany", treads on the Union Jack whilst he leaves the body of a woman he has stabbed in the back in his wake. The caption for this depiction of unchivalrous wickedness maintains the level of subtlety and proclaims "Murder!"

One could be forgiven for assuming the adversary described here is Germany, against which New Zealand was then committed to an intensive war effort. However, in fact the target of this depiction of thuggish behaviour was not "the Hun" or an 
enemy power, but Australia, New Zealand's close neighbour and ally (Figure 1). The piece appeared in the aftermath of an Australian plebiscite over the introduction of conscription which had resulted in a rejection of the proposal. The slain woman is labelled "conscription", the dagger "no" and the German elements are present to associate Australia's response with a perceived pro-German and disloyal disposition. According to a related editorial, "Australia by voting 'No-Conscription,' is proGerman, although it may not mean to be, but it is worse than that. Australia says definitely that the Empire is not worth fighting for" (New Zealand Observer, 5 January 1918: 2).

This depiction of a neighbour and ally, who committed no small amount of blood and treasure to the cause, as defective or disloyal was not some exceptional abnormality. Indeed such representations of Australia formed a recurring subject for New Zealand cartoonists during the war. In part this reflects the different wartime experiences of Australian and New Zealand societies during 1914-1918. As James Bennett (2004: 73) notes, "[i]n contrast with its bitterly divisive effect on the Australian labour movement, the war was largely a unifying force in New Zealand". However, as we shall see, it also reflects a larger pattern of layering meaning on transTasman differences. This article considers the critical role humour, or what can be construed as humour, played in this task by dissecting the anatomy of such cartoon representations of the trans-Tasman rivalry and considering their cultural context in wartime New Zealand.

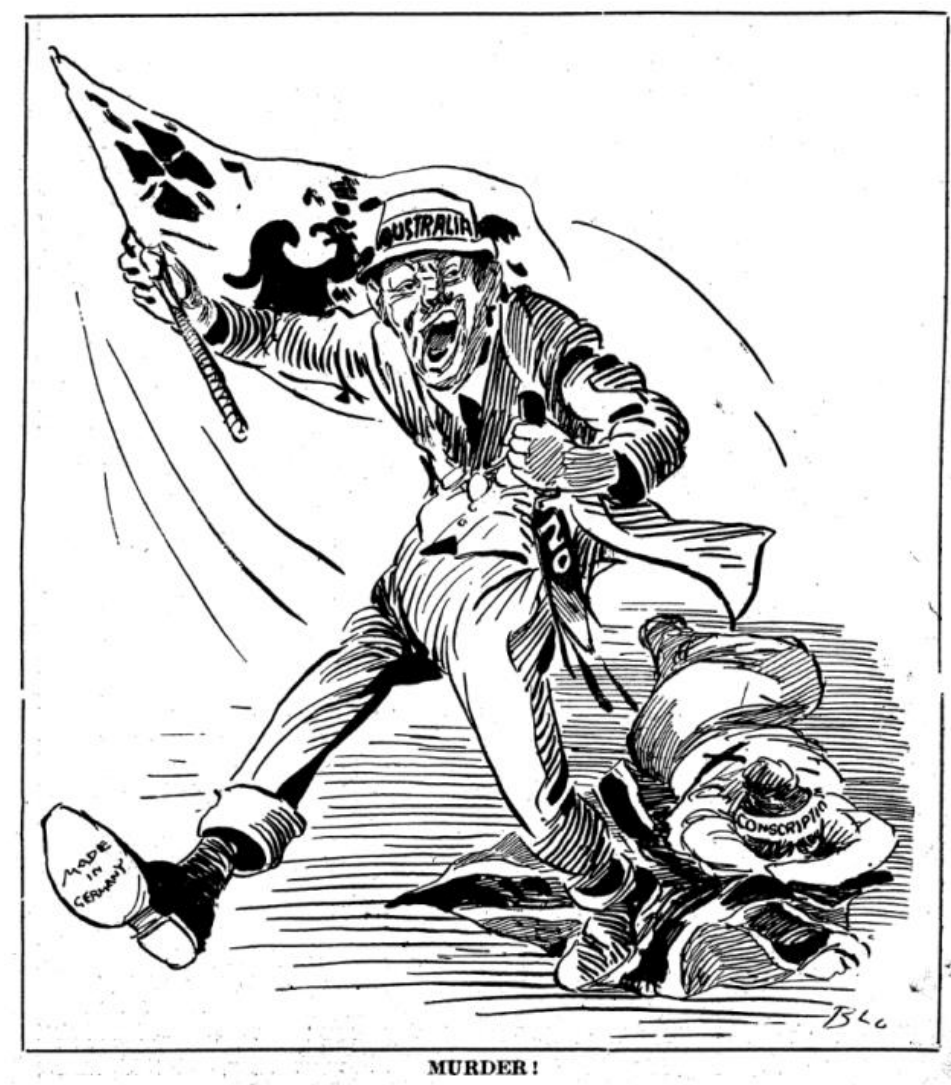

Figure 1. New Zealand Observer, 12 January 1918, p. 1.

The first step in this task is to recognise that such representations of Australia sit beside wider imaginings. The opening sketch of Australian wickedness for rejecting 
conscription, for example, stands beside very different depictions from other sectors of New Zealand society. Far from Figure 1's notion of Australia's misstep, the radical Maoriland Worker praised the rejection of conscription as inspirational, showing Australia as a free man advising imprisoned New Zealand to follow his example and free himself (Maoriland Worker, 15 November 1916: 1). Likewise, the muck-raking Truth depicted the Australian Prime Minister William Hughes, a leading voice in the call for conscription, being pummelled by a brawny arm labelled "Australian Democracy" (New Zealand Truth, 18 November 1916: 1). Furthermore, throughout the war, comradely images of New Zealanders and Australians as fresh-faced Dominion soldiers, possessing a shared kinship and united by a common ANZAC $^{1}$ ethos formed a popular motif. Various historical interpretations have investigated the wartime relationship of Australian and New Zealand soldiers, with some accounts noting a sense of comradeship blossoming against initial tensions and animosities (Stanley 2007). This sense of a combat-forged bond has remained a major part of public memory and modern mythology of the conflict. A recent New Zealand Government pamphlet marking the war's centenary offers a workable rendition of this theme, noting the war "created the bond with Australia that has continued down the generations" (author's collection).

It is because of the prominence of this wartime mythology that wartime vilifications of Australia may seem odd. However, the trans-Tasman relationship has historically featured both overwhelmingly peaceful, friendly, profitable relations and a rivalry capable of airing blunt, and sometimes cutting, expressions (McLean 2003). Although orthodox opinion states that this rivalry weighs less on the Australian mind, this discourse on those on "the other side of the ditch" (as the Tasman Sea is colloquially known) is a familiar activity within both countries. Indeed New Zealand's mixed wartime representations of Australia stand within, and are reflective of, a longer historical pattern wherein various visions of Australia have been advanced by various commentators in the service of various causes. Adding to the complexity, commentary on trans-Tasman unity and division transcends any neat factional, cultural or political division. All of the cartoonists examined here proved capable of producing alternatively antagonistic and comradely renditions of Australia. This reflects a wider idiosyncrasy of the trans-Tasman relationship where cultural representations evoking similarity, familiarity, association, perhaps even a shared identity, developed alongside those notions of difference, disassociation and distinct conceptions of self.

\section{Context in history and humour}

The complexities of this dynamic can be traced back into British settlement of the Australasian region. Shared heritage, colonisation, trade, migration patterns and political developments gave a shared past of trans-Tasman links and parallel experiences amongst the settlements (Mein Smith et al. 2008). Speaking of the nineteenth century one historian describes a regional community, the "Tasman world", as "loose, vague and semi-tangible" but as one with "real links beyond the conceptual" (Belich 2001: 47).

However, divisions and ideas of trans-Tasman difference are also recurring features within this history. New Zealand's history of "systematic colonisation", planned settlement, political arrangements with indigenes and theories of climatic determination all laid the basis for conceptions of New Zealand as a distinct region, 
and subsequent historical circumstances built on this conception. In 1901 the seven British colonies in the Antipodes were formally affirmed as two separate entities with New South Wales, Queensland, South Australia, Western Australia, Victoria and Tasmania forming the Commonwealth of Australia whilst New Zealand declined political union. This development marks both the ongoing development of transTasman difference and serves as a reflection of it. As a recent investigation puts it: "New Zealand's evolving national identity in the late nineteenth century was at the root of its lukewarm feeling for, and eventual rejection of, federation into the Commonwealth of Australia" (Palenski 2012: 167).

Humour, broadly defined, served as a key feature of this dynamic. This is perhaps due to how it could offer a sufficient and, largely, acceptable means to address trans-Tasman contradistinction; sufficient, because it functioned to chart, convey and imprint ideas of difference, and acceptable, because it did so in a way that did not compromise harmony. Indeed, trans-Tasman irreverence is conventionally construed as indicative of harmonious relations -as a good-natured ribbing between mates- where the central theme has been the distinction of "wowser New Zealand" from "larrikin Australia". As a contemporary joke book puts it, "New Zealanders see Australians as loud and uncouth, while Australians think of New Zealanders as slow and provincial" (Power 1993: 6). While there are limits in how stereotypes can capture complex realities it is remarkable how critics and admirers were able (and continue) to reference essential qualities, even as they judged them so differently. Thus commentators on both sides of the Tasman Sea presented New Zealand as a land of order/conformity, as dutiful/docile in its outlook and as respectable/puritanical in its social mores. Conversely Australia was envisioned as infused with a spirited/radical air, an unpretentious/vulgar tone and populated by a free/unruly people (Loveridge forthcoming). Consider how New Zealand interpretations of Australian rejection of conscription, both positive and negative, touched on a core image of Australia as unbound.

As these images suggest, the trans-Tasman rivalry continued throughout the war. During 1914-1918 cartoonists sought evocative ways to convey aspects of the war and rendered their points with increased conviction and less ambiguity (Murray 2012). Several harnessed the trans-Tasman rivalry to this task and depictions of Australia were used for various points within social commentary. The most prominent uses appeared in the pages of the New Zealand Observer, New Zealand Free Lance and the Auckland Weekly News. All of these publications pursued a populist approach seeking broad public appeal with a focus on sport, social commentary and illustrations. The cartoonists for these publications practiced a craft of punchy, and frequently biting, visual commentary, sometimes infused with an underlying bitterness that was often not far below the surface. The strident nature of the commentary also means that, while the cartoons have a base in humorous expression and utilise many humorous elements (satire, caricature, self-deprecation, exaggeration, etc.), few are likely to find much amusement in them. The result, together with the use of a friendly nation as a subject, might be considered as straddling the line of whether anything goes in humour.

Certainly these wartime depictions of the trans-Tasman rivalry represent a curiosity within considerations of wartime and political humour. Various works have probed the multifaceted applications of humour in times of crisis and conflict and the case has been made that humour should be considered as a legitimate part of cultural responses to the First World War (Purseigle 2001). Other investigations have focused on more specific dimensions of humour as a means to comprehend and process that 
war's ordeals. Combat studies, for example, have cited comedy as a coping mechanism used to buttress morale by interpreting circumstances positively or to make them less threatening (Watson 2008: 90). Similarly, humour and joking have been identified as relief valves both for addressing subjects, which may otherwise be off limits, and, seemingly paradoxically, for providing a means of distraction from harsh realities (Le Naour 2001: 4). Lastly, the shared, social nature of jokes (whether they are told or retold in private or public) has seen humour considered as a means of building or expressing solidarity, a covetable quality during times of crisis (Rudolph 2011). New Zealand wartime representations of Australia made varying uses of these qualities of humour. They can be seen as public efforts to raise the home front's awareness of the war effort and as sustaining tensions rather than distracting from or soothing them. Perhaps most crucially, by evoking the trans-Tasman rivalry they offered a means to interpret elements of New Zealand's war effort. The political dimensions of this use of humour fit within the well observed dynamic of reaffirming group identity and purpose via vilifying internal/external others (Kessel 2012). What is curious about much of the pictorial humour collected here, however, is how it put depictions of an external, friendly ally, and the various idiosyncrasies within New Zealand's relationship with that ally, to a comparable purpose.

\section{The trans-Tasman rivalry at war}

While the war disrupted many patterns of life, the fundamental features of the transTasman rivalry endured in wartime circumstances. For example, consider the way humorists made currency out of news that New Zealand troops were receiving illfitting uniforms, using an Australian presence to augment their points. Various wits worked the contrast between ideas of "the man in uniform" as imbued with an air of authority, decorum and sex appeal with satirical presentations of inglorious realities. Thus sketches of sentries, encamped within their uniforms, being mistaken for piles of clothes appeared alongside lampoons of officers ordering recruits to grow into their uniforms and jokes that the New Zealand soldier was cutting a poor figure in front of the girls (New Zealand Observer, 5 January 1918: 12; see also Lawson 1917). Puns included

All New Zealand soldiers have got the sack. It is stitched up the centre by brother Abraham and called "trousers".

and

"Have you ever suffered from fits?" asked the military doctor.

"No sir", said the examinee. "I'm a New Zealand military tailor".

(New Zealand Observer, 5 January 1918: 7)

Hank Portere's work When I First Put the Uniform On (Figure 2) fits into this context and again the New Zealand uniform's failure to charm "the girl in Blighty" is depicted. While the sketching of the second girl and the Australian soldier are technically superfluous in making the joke that English women might think New Zealander's are expected to grow into their uniforms, the trans-Tasman rivalry meant their presence could enhance the self-deprecation qualities of such jokes. Indeed the rivalry and sensitivity over New Zealand's smaller partner status means their 
inclusion augments the piece's impact and the mocking of the New Zealand soldier's uniform/appearance bites harder by contrast to the well kitted out Australian and the consequent female attention he receives.

Another aspect of the rivalry's place in wartime cartoons might be glimpsed in the New Zealand Observer's response to the war correspondent, Phillip Gibbs' comments on the exploits of the Australians and the New Zealanders during the Third Battle of Ypres (which would later come to be known as Passchendaele). Under the caption War Wonders (Figure 3) were a series of tongue in cheek illustrations printed beside Gibbs' comments. Several of the illustrations serve as light-hearted comic interpretations of Gibbs' words; his description of Australians as "lithe, loose-limbed, and hatchet-faced" and New Zealanders as "fuller built" and "more coloured" are illustrated with renditions of Australians as creatures of wire and axes and New Zealanders as Maori. Other sketches seem to play the "war wonders" description in a more subversive, eye rolling manner. Consider the rendition of Gibbs' comment that New Zealand soldiers "wanted to go as far as the Australians, and do as well as them" with an incredulous image of a New Zealand soldier with a bloody bayonet sitting on a pile of the enemy dead and telling a caricatured Gibbs "I want to be like a Horstralian". It is tempting to read the ridicule within this image against the assertions of an ANZAC historian who describes New Zealand's attitude towards Australian troops as a "love-hate relationship" where New Zealanders weighed a respect for Australian fighting qualities against their brashness and their own feeling of underrepresentation in ANZAC ephemera (Andrews 1993: 189).

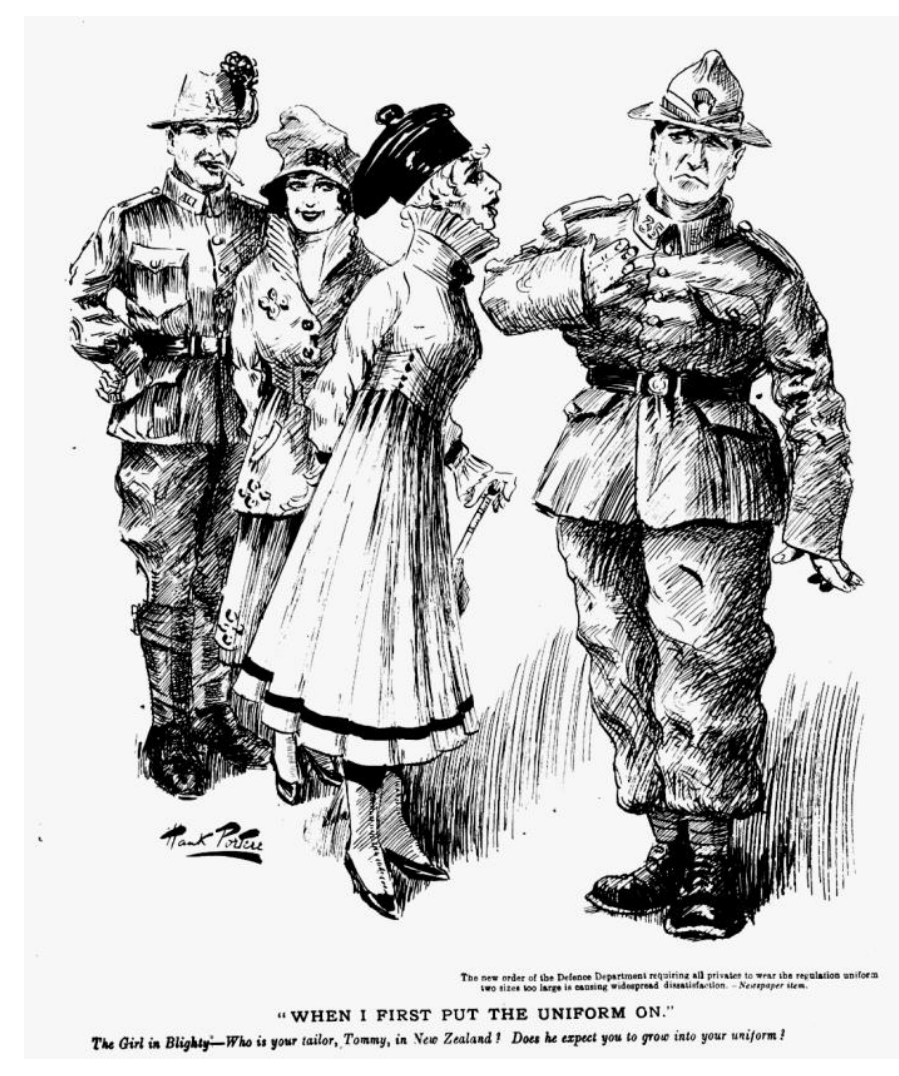

Figure 2. New Zealand Free Lance, 7 December 1917, p. 3. 


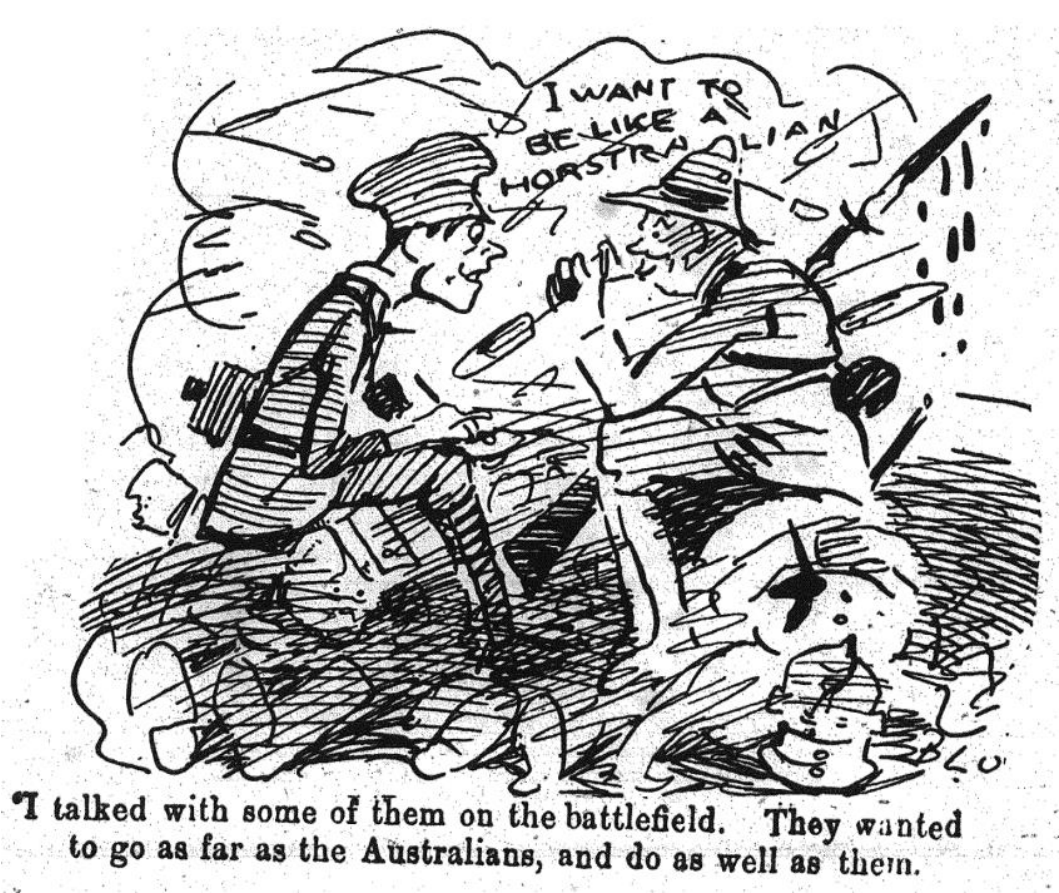

Figure 3. New Zealand Observer, 13 October 1917, p. 17.

\section{Australia's war effort as lacklustre}

Within other pieces, Australia formed a lesser antitype that could be used for finer points than the gross distinctions evoked by Manichean presentations of the enemy. If reports of German atrocities argued the case for the war effort's necessity and moral justifications, then representations of Australia could function to comment on how the cause was pursued. Consider Loyal Australia (Figure 4) which sardonically reported on recruitment in Australia by comparing images of a well attended racecourse with an almost barren recruiting office. The sense of public energy being misappropriated is impressed by the sheer mass of the crowds at the races and the activity of the bookmakers against the emptiness of the office, the underused administration and the overeager staff. Likewise, posters adorning the recruiting office urge the viewer to recognise their moral burden to the men at the front; "daddy died for you", "the ANZACs call you for help", "your country needs you". These dutiful calls are juxtaposed to speech bubbles at the racecourse which use militarised language in ironic ways such as "this is our battle" and "let's have a shot at the next race". 


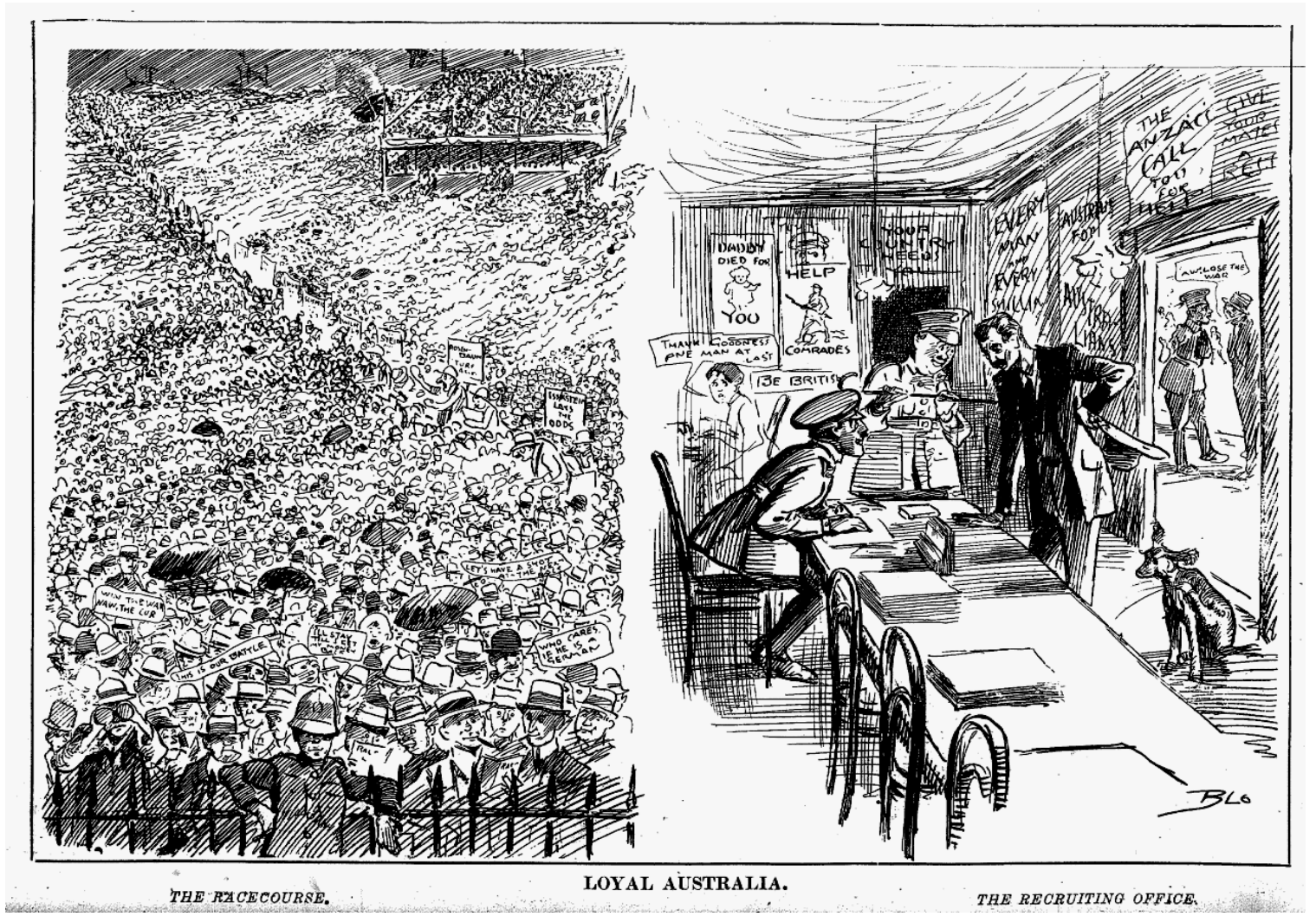

Figure 4. New Zealand Observer, 24 November 1917, p. 13.

Australia's Problem Shall We Desert our Soldier Boys (Figure 5) offers another depiction of Australia's effort as lacklustre and focuses on the consequent impact on the frontline soldier. With an Australian plebiscite on conscription to be held on 28 October, the piece depicted a wounded Australian officer telephoning Hughes from the "fighting front" noting that the battle was "at its hottest" but that help from the home front would see the soldiers win through. Against the seriousness of the scene at the dugout, impressed by the officer's injuries and an explosion in the background, Hughes reply, "Ah, er, um - we're about to take a referendum on the question" is cast as a less than resolute response. The soldier's exasperated reaction, "What's that? A referendum when we're fighting for our lives!", furthers the sense of Australia's politics as placing lives and victory in jeopardy. 


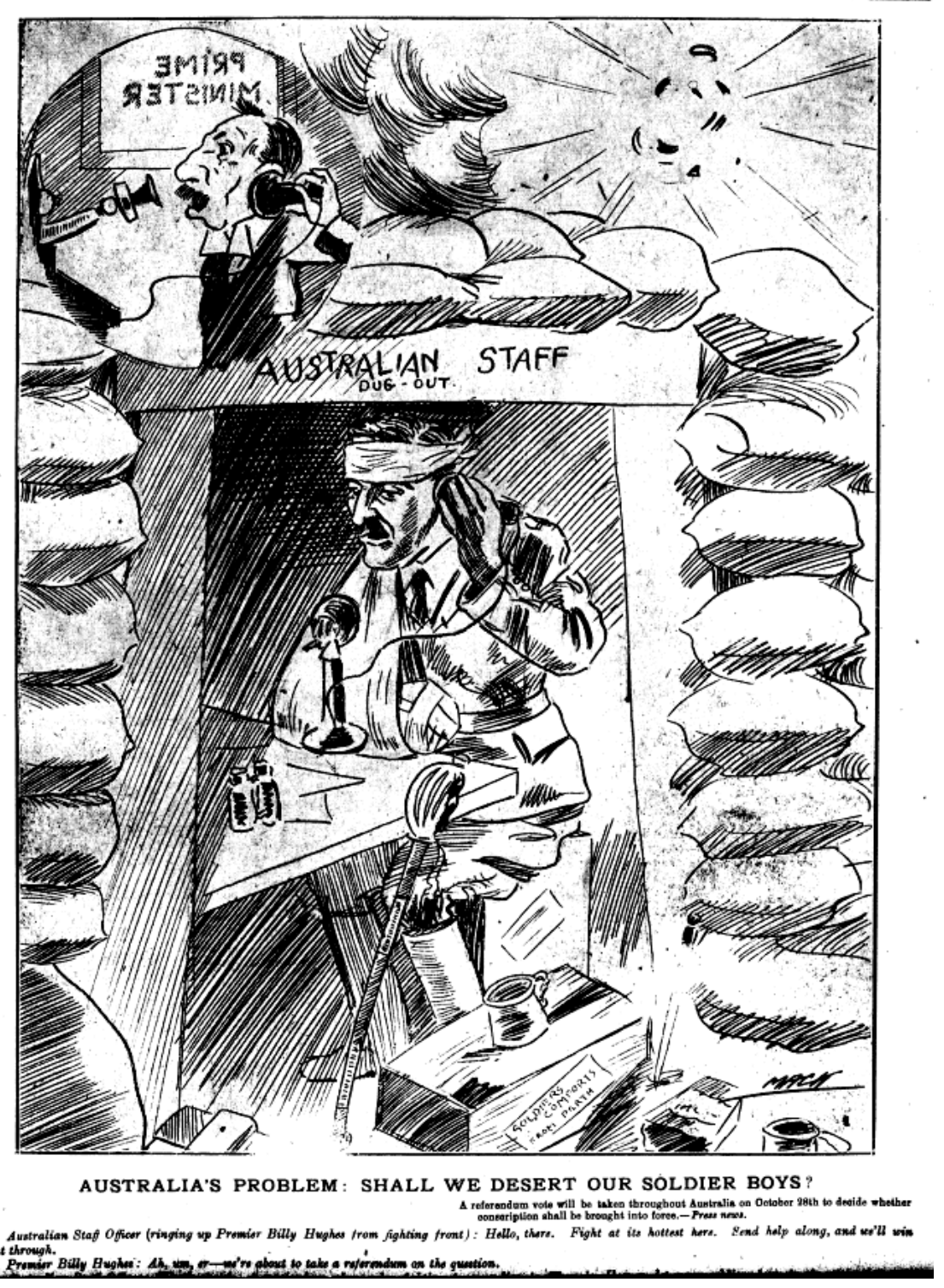

Figure 5. New Zealand Free Lance, 13 October 1916, p. 3.

Both images are indicative of how the trans-Tasman rivalry offered cartoonists a recognisable and convenient means to illustrate deplorable behaviour. Such lessons were directed less at Australia, which was likely paying little attention, than to expressing arguments within the New Zealand public sphere. They offered moral censures about a less than total commitment to the cause, with implicit points that New Zealanders should uphold higher standards than those depicted. Both aided those aligning New Zealand conscription (introduced June 1916) with support for troops and the cause. In this they are consistent with the line offered by other commentators who argued that conscription was a sign of national commitment and an equitable and efficient means to ensure that the war effort and economy were protected from those who would shirk their duties. 


\section{1916 plebiscite}

The use of cartoons to present deplorable behaviour would continue with Australia's division over conscription. New Zealand had enacted conscription under the Military Service Bill in mid 1916. The legislation passed with an overwhelming parliamentary majority: the final reading producing 44 ayes against four nays (New Zealand Parliamentary Debates 175: 786). The lack of a New Zealand referendum on conscription makes determining the wider popularity of the bill difficult. Various studies have charted instances of dissent and resistance; major examples include the emergence of the modern Labour Party, the sedition charges levelled at several labour leaders (including a future Prime Minister) who called for a repeal of conscription, strike threats from several unions, hundreds of men who went to jail after refusing their call up and less recorded cases of men heading into the wilderness or leaving the country in efforts to place themselves beyond conscription's reach (Belich 2001: 101102). However, the foremost study on the topic regards New Zealand's introduction and application of conscription as "first and foremost, an expression of the popular will", and estimates that between 60-70 per cent of New Zealanders were in favour of conscription and that no more than 20 per cent were opposed (Baker 1988: 98, 230).

Within Australia, the October 1916 plebiscite revealed a far more divided society with the "no conscription" vote garnering 1,160,033 votes against 1,087,557 in favour (Beaumont 1995: 50). Explanations for the different reactions to conscription have been considered in various studies (Levi 1996: 133-167; Loveridge 2014: 240-241). For their own part, contemporary New Zealand cartoonists also offered their sense of trans-Tasman difference. In this task, trans-Tasman similarities could be an asset, with resemblance allowing cartoonists to use Australia as a foil to highlight key differences in New Zealand's qualities and circumstances. Consider It's an Ill Bird That Fouls Its Own Nest (Figure 6) where news of the results was presented via a trans-Tasman vista, comparing regimented Kiwi chicks, who line up behind a national bird to spell conscription, with an Emu whose nest egg, labelled conscription, has broken open. Also playing to the theme of Australian dysfunction, Trevor Lloyd depicted the result with The Blot on Australia (Figure 7). Here the word "no" stains the continent, marking New South Wales, Queensland and South Australia where the "against" vote had carried (Beaumont 1995: 50). The caption references the frequent wartime remark of Germany or Prussian militarism as "the blot on the map", which should be "wiped up". The redirection of the expression to Australia likewise conveyed the idea that the result represented a blemish on the Australian landscape that should be addressed. This core concept could accommodate various lines of commentary. Alongside some previously seen notions of Australia's insufficient dedication to the cause and pro-Germanism, some suggested Australian ancestry might hold a clue and G. W. Russell, New Zealand's Minister of Internal Affairs, pondered if the plebiscite result had something to do with the "convict taint" (Truth, 11 November 1916: 1). 

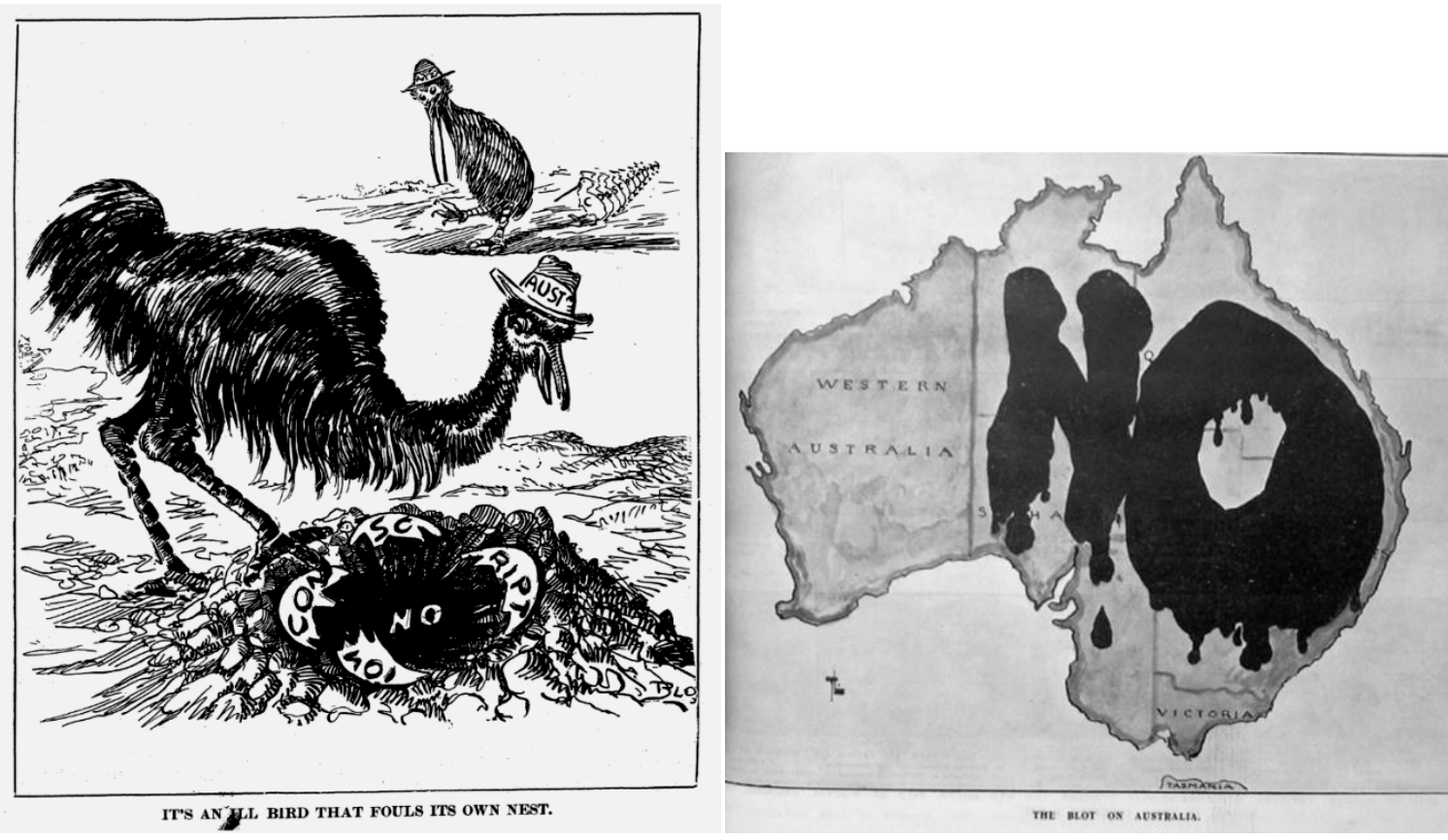

Figure 6. New Zealand Observer, 11 November 1916, p. 1.

Figure 7. Auckland Weekly News, 18 November 1916, p. 39.

\section{Industrial unrest}

The image of Australian society as blemished would also appear to reference strained industrial relations during the war and present the sense of Australia's war effort as being undermined by radical elements. While news of labour unrest anywhere could potentially serve as a warning for disunity, there was a history of citing Australian militancy as alien to the spirit of New Zealand social relations and system of industrial arbitration. As Rollo Arnold (1988: 67) puts it, "[t]he Red Fed serpent which had plotted against this Arcadian vision by offering an alternative socialist myth had too often spoken with an Australian accent".

Certainly volatile labour relations offer a perspective of the fragmentation of Australian society during the war. In July 1915 various elements of the union movement declared themselves against compulsion with the Trade Hall Council in Melbourne and a conference of Victorian unions making comparable declarations in September (Beaumont 1995: 44). Other aspects of the movement made qualifications; the NSW Labour Council carried a motion rejecting conscription if not accompanied by a conscription of wealth (Beaumont 1995: 44). In 1916 industrial unrest and strikes in Sydney affected munitions production. In response the New Zealand Free Lance illustrated the episode with The Red Fed Brand of Patriotism (Figure 8). Within the image a "Red Fed" (the popular name for the New Zealand Federation of Labour) striker hampers a soldiers' sword arm in the middle of a fierce battle whilst proclaiming his demands for better conditions. The sense that strikers were impeding the nation's cause (which the caption and the soldier's hat label explicitly link him with) leads naturally to the sense that they were consequently aiding Germany.

Australia's worst wartime strike took place in August 1917 commencing with New South Wales railway workers protesting over the introduction of timecards. Unrest spread until an estimated 100,000 workers, 14 percent of the NSW workforce, 
were involved. Shipping was paralysed and saw consequent restrictions on food and fuel. The whole affair lasted six weeks and saw the loss of 4,000,000 working days (Haig-Muir 1995: 112). Within Australia, the syndicalist International Workers of the World (I.W.W.)'s longstanding opposition to the war, promotion of industrial action and instigation of an Anti-Conscription League had made it a focus of commentary on unrest and governmental reaction (Beaumont 1995: 44, 48). This included the jailing of twelve members in New South Wales on charges of sedition and designs to burn down Sydney and the suppression of the organisation under the Unlawful Associations Act, passed 19 December 1916 (Cain 1982: 54-62; Grey 2008: 114). In depicting the strikes, New Zealand cartoonists focused on the I.W.W. in associating radical labour with ideas of danger and shame - the Bolshevik revolution would soon provide another major touchstone. Consider, Australia (Figure 9) where the previously encountered blot reappears, identified as the I.W.W. and is shown as staining the Australian flag.
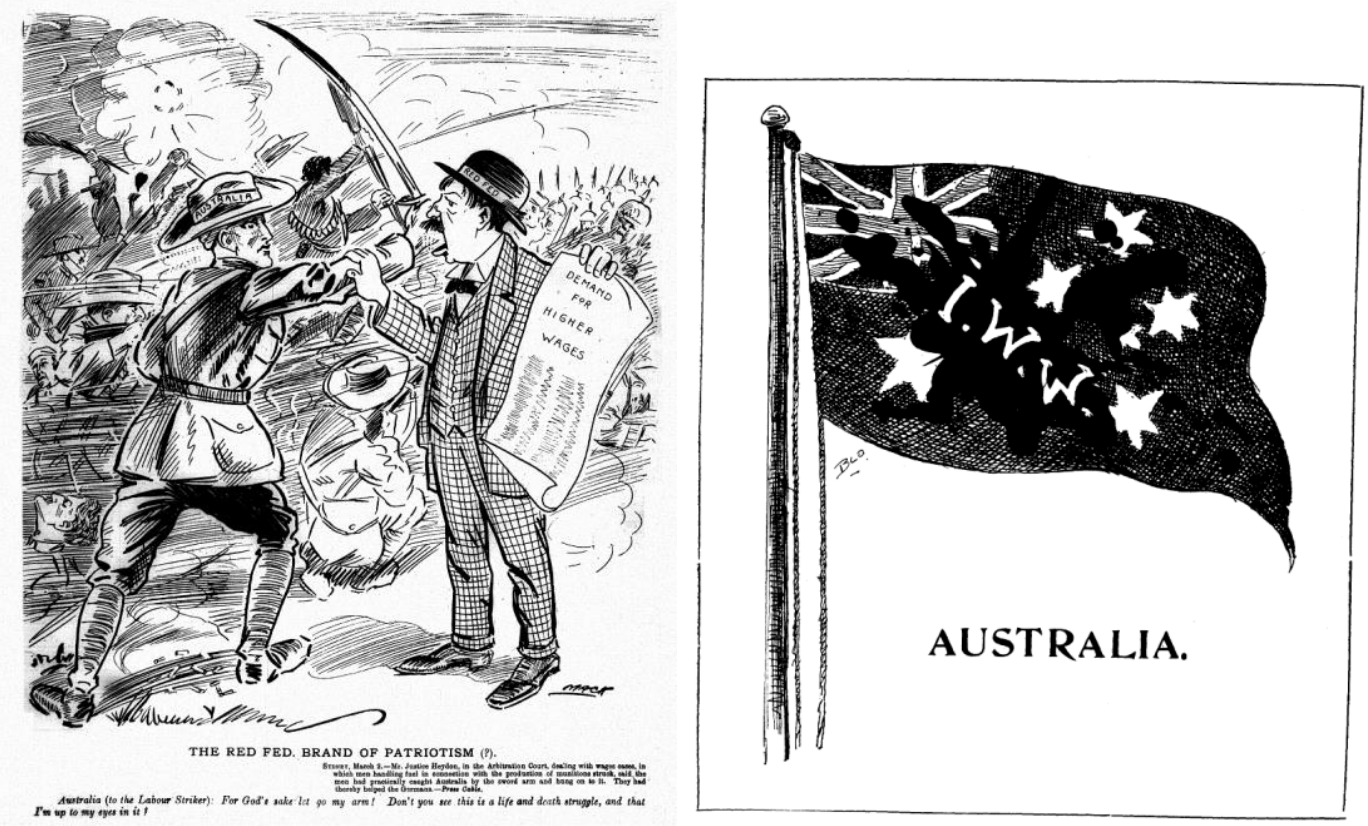

Figure 8. New Zealand Free Lance, 10 March 1916, p. 3.

Figure 9. New Zealand Observer, 25 August 1917, p. 1.

Also responding to the strike, Trevor Lloyd sketched Scotched (Figure 10). The image presented the I.W.W. as a serpent entwined around the country with its maw positioned over Sydney, and Hughes as attempting to pin the beast. Again, visions of radical Australia could draw upon the possibilities geographic and cultural proximity offered. A vision of a fellow British Dominion tainted by radicalism or disloyalty facilitated a notion of "it can happen here". This was the frank message of a New Zealand Free Lance editorial. "It has been clearly proved in Sydney that German influence was at the back of the incendiarism and murder with which the I.W.W. men are charged. What has been done in Sydney may be done here!" (New Zealand Free Lance, 13 October 1916: 6). 


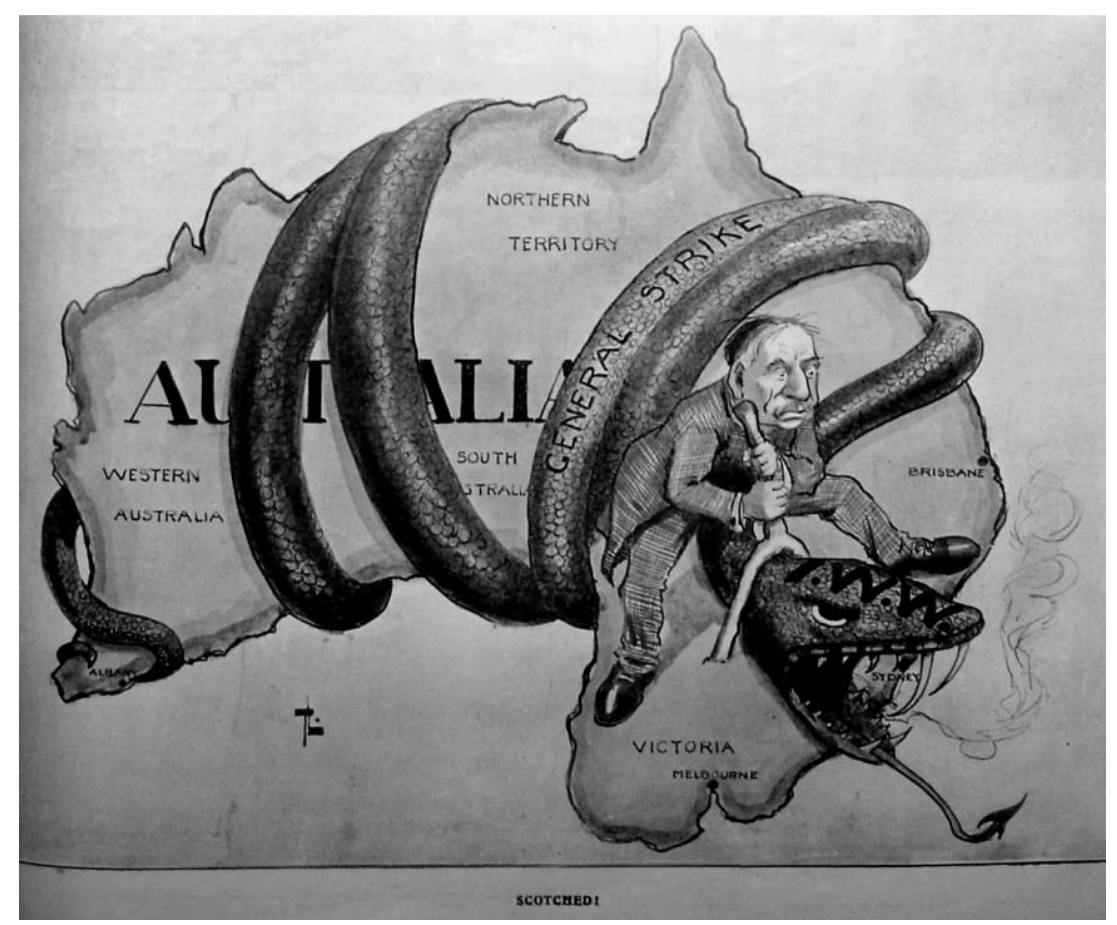

Figure 10. Auckland Weekly News, 20 September 1917, p. 33.

\section{1917 plebiscite}

The sense of Australian division as an antitype flared again as, on 7 November 1917, Hughes announced the government's decision to hold a second plebiscite on the introduction of conscription. This second campaign took place in a war-weary society in which division and hardened opinions permeated large sections of the public (Grey 2008: 115). This division is most evident in the political fallout from the first plebiscite which had fragmented the Labour Party at federal and state levels; in all states except Western Australia parliamentarians who supported conscription had been expelled (Beaumont 1995: 50). The disintegration of Hughes' power base had been shorn up only through the formation of a National coalition government. Likewise the hardening of public opinion is observed in the entrenchment of the anticonscription position with the same arguments being raised, though the clashes of opinion are noted as "more violent, more emotional, more final" (Robson 1982: 168).

Again New Zealand cartoonists depicted this division within the context of the trans-Tasman rivalry and used this relationship in making various points. This is evident in pictorial commentary in the lead up to the Australian plebiscite. Consider Hank Portere's Will Australia Play the Game? (Figure 11) printed the day before the vote. Comparing the two countries efforts, the piece portrays the New Zealand Prime Minister William Massey's "conscription magnet" as pulling men partaking in leisure activities into service while Hughes" "voluntary system magnet" is unable to attract the unenlisted men who mill around his feet. Referencing these results Massey dismisses Hughes" "footling little toy", notes that conscription is the only tool to "do the job" and suggests he try it. Trevor Lloyd likewise met the second plebiscite with a depiction of Hughes and a question, asking Will Australia Rub out the Blot? (Figure 12). Here he returned to his 1916 image of the first plebiscite result (Figure 7) but added Hughes working to erase the blot from the country. The question of whether he would successfully remove the stain, in the upcoming plebiscite, is left open. 
Ultimately Australia would confirm its rejection of conscription by an increased, though still close, margin of 1,015,159 for, to 1,181,747 against (Beaumont 1995: 54). This result returns us to the context of Figure 1's sense of Australia as dysfunctional and disloyal. Others depicted this result as shameful by casting Australia in the role of the shirker. A common wartime antitype, the shirker was typically portrayed as a physical degenerate who lacked civic virtue and moral fibre. Other standard features include dandyish fashions, a failure to roll up sleeves, a favouring of trivia or luxuries (such as sports and smoking) over duty and faux genteel language (Loveridge 2013).
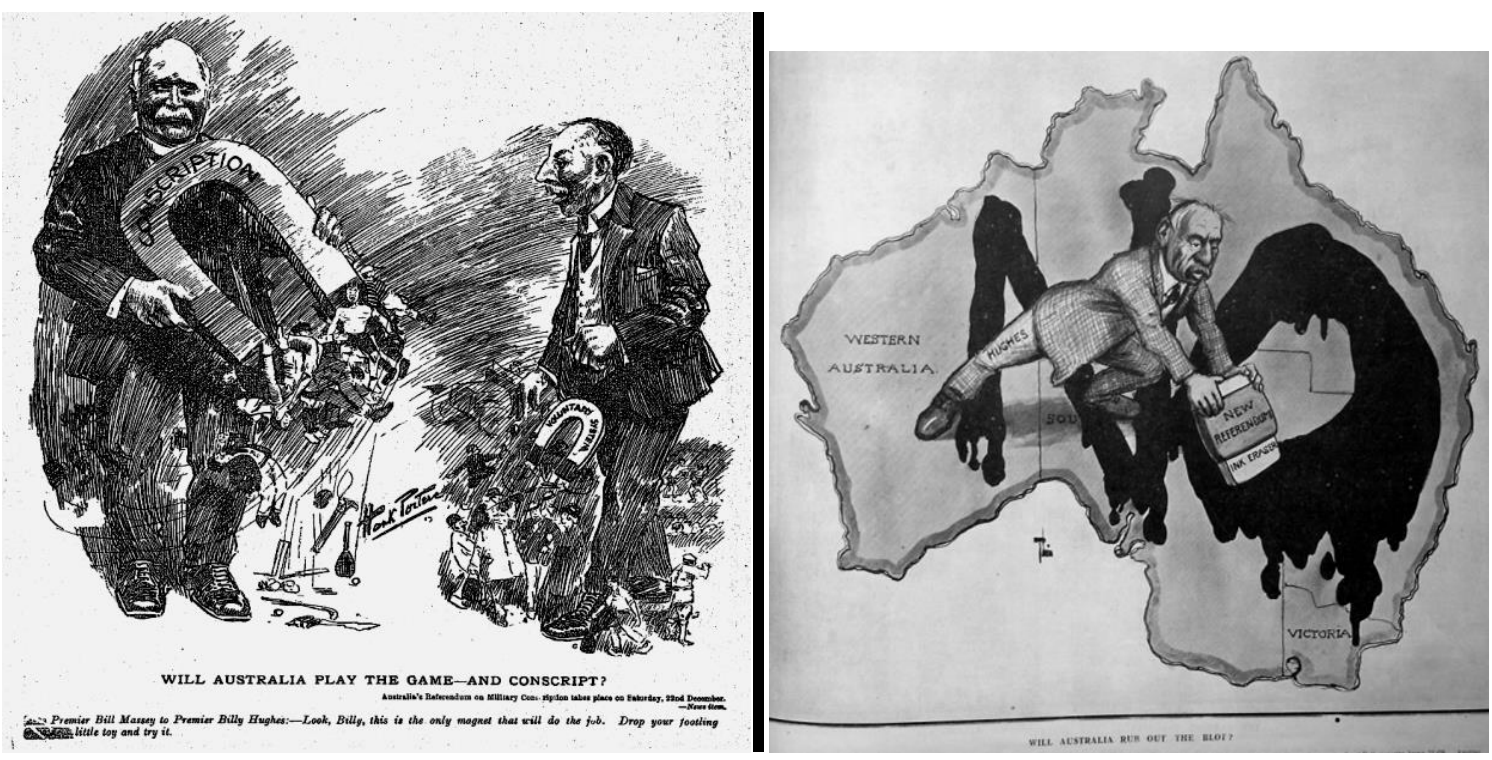

Figure 11. New Zealand Free Lance, 21 December 1917, p. 3.

Figure 12. Auckland Weekly News, 22 November 1917, p. 35.

The stock character nature of the shirker meant that shirking tropes could be applied to a country to achieve a comparable effect. Until the United States of America entered the war in 1917, cartoonists offered the occasional depiction of that country in this manner, often citing that materialism had made Americans apathetic and/or unprincipled. However, depictions of Australia as a shirker could draw upon imperial relations and play them out within the trans-Tasman rivalry. For example, depicting the plebiscite result, Australia's "No" (Figure 13) sketched Australia as refusing to help put out the flames of German Kultur and as the listless member of the imperial family. Contrasting to the activity, urgency and solidarity displayed by John Bull, Canada, India, New Zealand and New Foundland, Australia is adorned with standard shirker tags and is depicted as more interested in smoking, sports news and leaning on a well placed post. Finally, Australia's captioned line, "It's your crimson crib, not mine. Do your own bally blanketty work" attributes this behaviour to dishonourable indifference. 


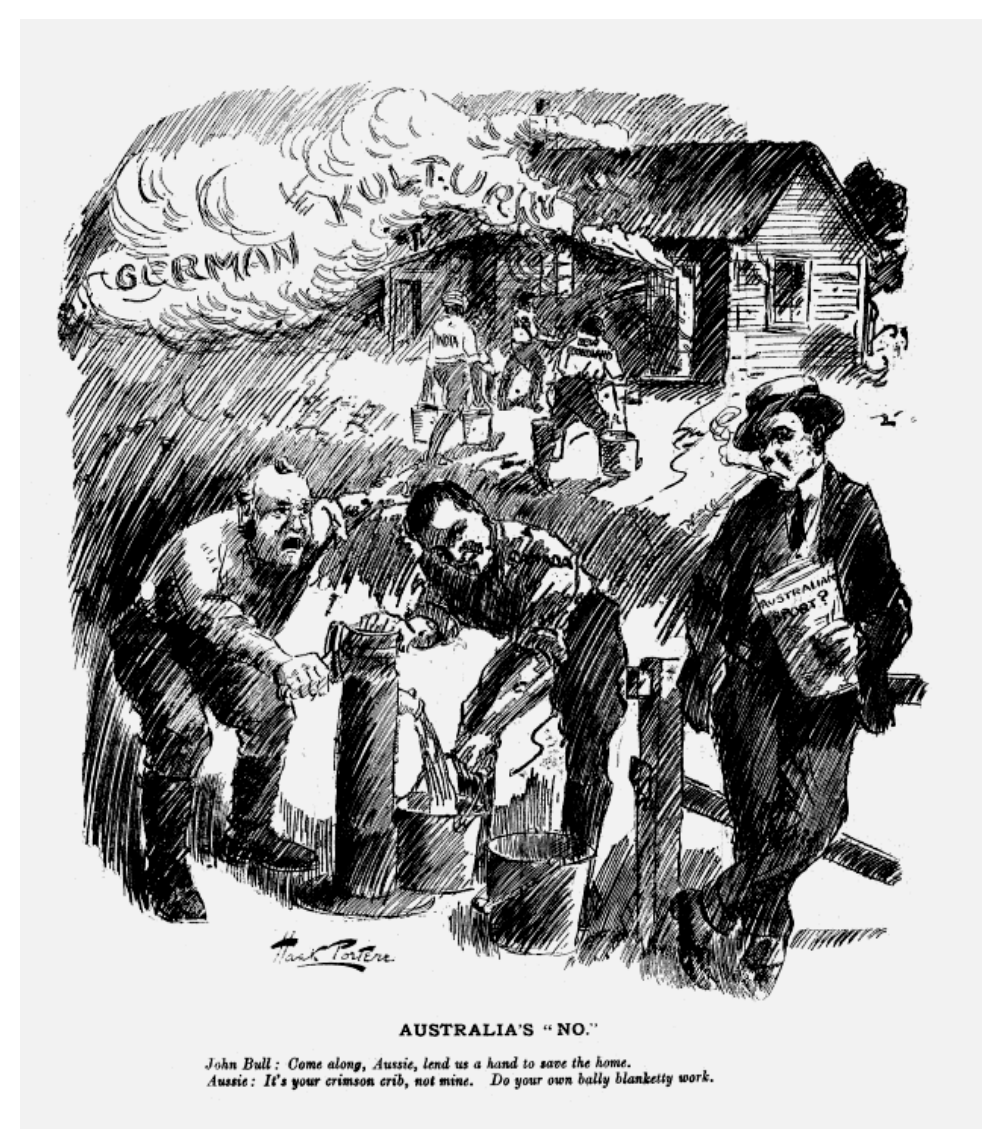

Figure 13. New Zealand Free Lance, 4 January 1918, p. 3.

Another bitter accusation of shirking appeared a few weeks later in the New Zealand Observer's leading cartoon No Surrender - No Fight (Figure 14). Here, "No conscription Australia", is presented as at ease reclining, smoking and possessing racetrack tickets and an anti-conscription pamphlet. Adorned with these indicators of indifference to the cause, "Australia" clutches reports of Germany's Pacific colonies, which both Australia and New Zealand had designs for in post-war settlements. The caption furthers the sense of Australia as parasitically wanting the spoils of war without committing to the fight noting "what you've won we'll have".

\section{Conclusion}

Over the course of the war, New Zealand cartoonists repeatedly penned images of Australia that might seem contrary to notions of friendly New Zealand/Australia relations in general and wartime solidarity in particular. It may be tempting to consider these works as testing the limits of the good-natured ribbing and the humorous irreverence conventionally considered to be a key aspect of the transTasman association.

However, these representations are also reflective of the established idiosyncrasies of the trans-Tasman relationship which predated, and outlasted, the war. In a sense it is unsurprising that a war which mobilised so much of public life saw the trans-Tasman rivalry feature within New Zealand's cultural panorama of the war as sketched by cartoonists. Indeed the qualities of this dynamic proved useful to cartoon commentators contemplating aspects of New Zealand's war effort. 
Commentary on the advantages of conscription and the importance of social unity, for example, could draw upon depictions of Australian circumstances and conditions in making their point. The use of Australia as a subject within these messages also reflects the familiarity built up within Tasman relations. Many of the pieces examined here simply would not work, or work to the same extent, without the public's broad familiarity with Australia.

Appreciating the broader context of the cartoons also aids in reconciling the antagonistic images surveyed here with the benign relations both countries enjoy. Indeed it is worth restating that Figures 1-14 stood beside, and were significantly outnumbered by, more positive renditions of Australia, and that these were produced and circulated by the same artists and publications examined in this article. In this way these cartoons serve as a good indication of the mixed currents of the transTasman relationship and the complex place of humour therein.

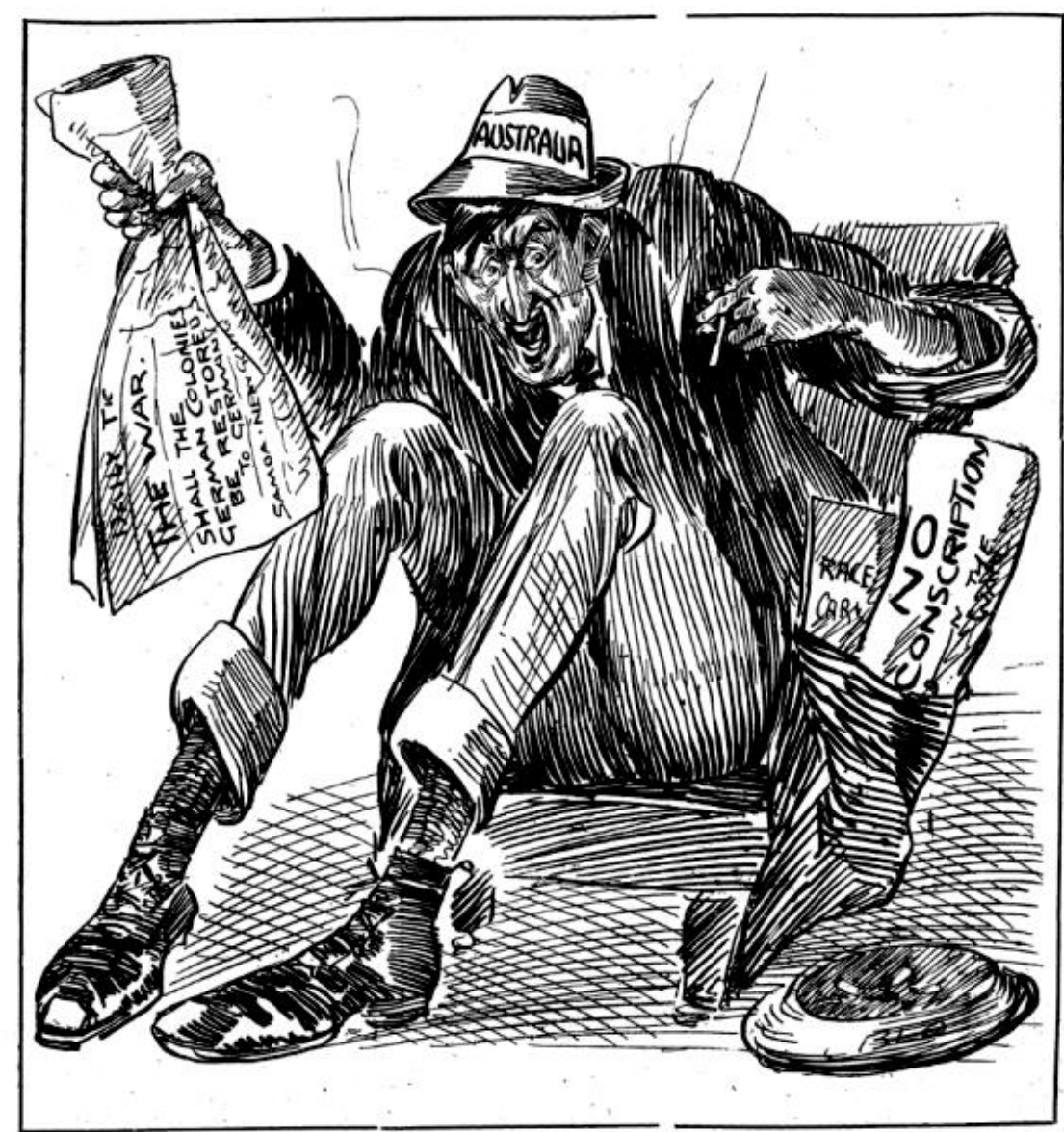

NO SURRENDER-NO FIGHT.

No Conscription A ustralia : Give up the German colonies?' Na-ous, not on yer lifel What you' ve won we'll have.

Figure 14. New Zealand Observer, 9 February 1918, p. 1.

\section{Notes}

1 ANZAC (The Australian and New Zealand Army Corps) was an army corps primarily comprised of troops from Australia and New Zealand. The concept that an ANZAC ethos or spirit infused this body has become a public touchstone in both 
Australia and New Zealand. The typical character portrait emphasises physical and mental toughness, a humorous spirit, a natural propensity for egalitarianism, a talent for ingenuity and mateship.

\section{References}

Andrews, E. M. (1993). The Anzac Illusion: Anglo-Australian Relations during World War I. Cambridge: Cambridge University Press.

Arnold, Rollo. (1988). 'The Australasian peoples and their world, 1888-1915', in Sinclair, Keith (ed.), Tasman Relations: New Zealand and Australia, 1788-1988, Auckland: Auckland University Press, pp. 52-70.

Baker, Paul. (1988). King and Country Call: New Zealanders, Conscription and the Great War. Auckland: Auckland University Press.

Beaumont, Joan. (1995). 'The politics of a divided society', in Beaumont, Joan (ed.), Australia's War, 1914-18, St Leonards: Allen \& Unwin, pp. 35-63.

Belich, James. (2001). Paradise Reforged: A History of the New Zealanders from the 1880s to the year 2000. Auckland: Allan Lane.

Bennett, James. (2004). Rats and Revolutionaries': The Labour Movement in Australia and New Zealand. Dunedin: Otago University Press.

Cain, Frank. (1982). 'The industrial workers of the world: Aspects of its suppression in Australia'. Labour History 42, pp. 54-62.

Grey, Jeffrey. (2008). A Military History of Australia, 3rd edition. Port Melbourne: Cambridge University Press.

Haig-Muir, Marnie. (1995). 'The economy at war', in Beaumont, Joan (ed.), Australia's War, 1914-18, St Leonards: Allen \& Unwin, pp. 93-124.

Herzog, Rudolph. (2011). Dead Funny: Humor in Hitler's Germany; translated by Jefferson Chase. Brooklyn: Melville House.

Kessel, Martina. (2012). 'Introduction: Landscapes of humour: The history and politics of the comical in the twentieth century', in Kessel, Martina and Merziger, Patrick (eds.), The Politics of Humour: Laughter, Inclusion, and Exclusion in the Twentieth Century, Toronto: University of Toronto Press, pp. 3-21.

Lawson, Will. (1917). Current Cartoons. Wellington: W. Macbeth.

Le Naour, Jean-Yves. (2001). 'Laughter and tears in the Great War: The need for laughter/the guilt of humour'. Journal of European Studies 31 (123), pp. 265-275.

Levi, Margaret. (1996). 'The institution of conscription'. Social Science History 20 (1), pp. 133-67.

Loveridge, Steven. (2013). "Soldiers and shirkers" Modernity and New Zealand masculinity during the Great War'. New Zealand Journal of History 47 (1), pp. 5979.

Loveridge, Steven. (2014). Calls to Arms: New Zealand Society and Commitment to the Great War. Wellington: Victoria University Press.

Loveridge, Steven. (forthcoming article accepted for publication). "The "Other" on the other side of the ditch?: The conception of New Zealand's disassociation with Australia'. Journal of Imperial and Commonwealth Studies.

Maoriland Worker

McLean, Denis. (2003). The Prickly Pair: Making Nationalism in Australia and New Zealand. Wellington: University of Otago Press. 
Mein Smith, Philippa, Hempenstall, Peter and Goldfinch, Shaun with McMillan, Stuart and Baird, Rosemary. (2008). Remaking the Tasman World. Christchurch: Canterbury University Press.

Murray, Sarah. (2012). A Cartoon War: The Cartoons of the New Zealand Free Lance and New Zealand Observer as Historical Sources, August 1914-November 1918. Wellington: New Zealand Cartoon Archive.

New Zealand Free Lance

New Zealand Observer

New Zealand Parliamentary Debates

New Zealand Truth

Palenski, Ron. (2012). The Making of New Zealanders. Auckland: Auckland University Press.

Power, Katrina. (1993). Favourite New Zealand Jokes About Australians. Auckland: Reed.

Purseigle, Pierre. (2001). 'Mirroring societies at war: Pictorial humour in the British and French popular press during the First World War'. Journal of European Studies 31 (123), pp. 289-328.

Robson, L.L. (1982). The First A.I.F.: A Study of its Recruitment 1914-1918. Carlton: Melbourne University Press.

Stanley, Peter. (2007). "Whom at first we did not like...": Australians and New Zealanders at Quinn's Post, Gallipoli', in Crawford, John and McGibbon, Ian (eds.), New Zealand's Great War: New Zealand, the Allies, and the First World War, Auckland: Exisle Publishing, pp. 182-193.

Watson, Alexander. (2008). Enduring the Great War: Combat, Morale and Collapse in the German and British armies, 1914-1918. Cambridge: Cambridge University Press. 